\title{
The Fluency of Oral Reading with Natural Reader Software
}

\author{
Varia Virdania Virdaus $^{(1)}$, Saiful Rifa'i ${ }^{(2)}$ \\ ${ }^{(1)}$ Universitas Narotama, Indonesia \\ ${ }^{(2)}$ Universitas PGRI Adibuana Kampus Blitar, Indonesia \\ E-mail: (1)varia.virdania@gmail.com, ${ }^{(2)}$ rifai.saiful@gmail.com
}

Received: 12 October 2021; Revised: 26 November 2021; Accepted: 27 November 2021

\begin{abstract}
This recent investigation aims to find out whether natural reader software improves oral reading fluency for English language learners. In this recent study, the natural reader software was considered as independent variable and the oral reading fluency score was regarded as dependent one. The subjects of this investigation were students of English education study program. The number of the students of group (1) were 32 students who are taught using natural reader software and this group was considered to be an experimental group and The number of the students of group (2) were 35 students who are taught without using natural reader software this group was considered to be control group. This study has proven that this software can significantly prove that most of students have more accurate and more precise reading skills. This study has revealed that oral reading fluency instruction does improve global reading proficiency at all grade levels.
\end{abstract}

Keywords: natural reader sofware, teaching, oral reading fluency

\section{Introduction}

As an international language, everyone must learn English so that they can adapt to the era of globalization. Communicative needs are needed by Indonesian people because English is a second language but a foreign language in Indonesia (Wati, 2011). English has four skills that should be gained, namely writing, reading, listening and speaking. However, with this article, the author only discusses the skill of reading that are focused on the fluency of oral reading.

The fluency of oral reading is a skill needed to be developed by everyone because it is assumed that all people who are fluent in reading have the ability to read comprehensively and have appropriate speech skills... underlying relationship between the fluency of reading and reading comprehension, specifically the students having difficulties of reading, might be new for some English teachers (Pikulski \& Chard, 2005). (Bethesda, n.d.) has pointed out that there have been so many reading specialists and teachers are now paying much attention to their students' fluency skills. Reading fluency is correlated to the accuracy elements in speaking, expressions and right speed (Rasinski, 2004). He further has stated that if some readers can master reading at the elementary level, then they can understand much deeper about the meaning of reading which is contained in the reading text. The aim is to improve the fluency of reading and to increase the understanding level of the reader.

There is evidence that there is a study showing that some students if repeatedly want to read the same paragraph, it is proven that the number of errors will be reduced and there is an raise in reading speed and an increase in their oral reading expression. There is also a similar study that shows that there is a relationship between fluency and standard reading test scores (Yildiz \& Çetinkaya, 2017). There are clear indicators between accuracy and speed and it is very easy to observe from students' ability to read aloud. It is clear that fluency in reading is a very dominant element of students' reading skills (Bethesda, n.d.).

Based on some of the statements above, It has been proven that oral reading has a strong relationship with reading comprehension, there- 
fore having good oral reading skills is very important, but unfortunately, it is very rare for the syllabus of the English department, including the English Department of UNIPA Blitar campus, to include fluent reading courses in its curriculum structure. (Rasinski, 2004) has also declared that the fluency of reading has not received attention for many years, Furthermore, he has also pointed out that most schools, most English teachers, some administrators of the schools, many also writers of textbooks, some of the teachers working for programs of preparation, and some others do not at all place that reading fluency is very important in reading education. Those may be one of the causes of the student's inability to understand reading texts. Some experts (Demars \& Erwin, 2005) state that reading fluency is very poor it seems to be the biggest disturbance in understanding reading comprehension text.In this study, the researcher would like to describe: Whether the Natural Reader software can increase the oral reading fluency of English learners.

\section{Materials and Methods Fluency}

(Rasinski, 2004) specify that good public speaking is a good analogy for learning reading fluency. Fluent public speakers inevitably imprint in their voices some of the same elements related to reading fluency - accuracy when they speak, the speed at reading text, and very precise phrases and expressions. The aspect of fluency used by these speakers will facilitate the understanding of the listeners. Phrases that are used correctly, emphasize certain words, increase and decrease the volume, and the application of various intonations will greatly help listeners to easily understand what the speaker is saying. The competence to read texts quickly, accurately, and expressively are the hallmarks of fluency in reading texts. Fluency is a very important element because fluency provides a bridge between recognizing and understanding words, phrases, and sentences. When readers are very fluent in reading the text silently, they will know the exact words, phrases, and sentences automatically. Readers will classify words quickly and accurately so that listeners get meaning from what they read. Readers who still cannot expand their fluency will read gently, words for words. Their fluency of oral reading will not be choppy, because to decipher words, for very fluent readers there is no need to concentrate, the reader will usually be able to focus the listener's attention on the meaning of the text. The relationship between ideas contained in the text and the background knowledge they have, can be made by the reader. In other words, the readers who are already very fluent will know the words and they will be able to understand them as they read. It is different for readers who are still not fluent; they must focus the listener's attention on finding out the words, and leave the listener a little scrutiny to know the text meaning.

The new recognition as a very important element of any reading program is reading fluency. In addition, reading fluency is one of the characteristics that can determine that someone is a good reader, and not fluent reader in reading is a general feature of bad readers. Reading fluency can distinguish between good and bad readers, but the not fluent reader in reading texts is a real indicator of the problems of reading comprehension.

\section{The Scale of Multidimensional Fluency}

To assess fluency in the areas of volume and expression, expressions, fluency, and speed should use the following rubrics $(1-4)$.

\section{Volume and Expression}

a. reading the words as if just to result a little impression of attempting to make the text sound like the nature of the language.

b. starting to use voice to make the text sound like the nature of the language in parts of the text but not in other parts. Most focus should remain on the pronunciation of the words.

c. reading the text that sounds like the nature of the language along with the better part of it. Sometimes slipping into expressionless reading. Volume is generally proper along with the text.

d. reading with great expression along with the text. Vary expression and volume to meet their understanding of the meaning of the passage.

\section{Phrases}

a. Reading monotonously with phrase limits often reading word for word

b. Reading broken word by word, it seems that the reading is disjointed, the stress is not right, and the intonation falls in ending sentences and clauses.

c. Reading that sounds a batter of run-ons, pauses in the middle of sentences 
caused to take a breath, and a slight stutter, reasonable stress, and intonation.

d. Usually reads with good phrases, and mostly in words, clauses, and unit sentences, with adequate attention to ex-

Smoothness pression.

a. Make very frequent pauses where the pause is extended, always hesitate, often make the wrong start, and often make repetitions.

b. Make some "rough points" in the text where pauses or extended hesitations are more common.

c. Usually breaks rhythm due to difficulty with certain words and phrases.

d. Reading fluently with a few pauses usually occurs, but usually, through self-correction, word and structure difficulties can be resolved quickly.

Pace

a. It is necessary to read slowly and with difficulty

b. Required quite slow reading

c. Required reading with an uneven mix of fast and slow

d. it is necessary to read consistently at a conversational pace, at a suitable rate during reading.

\section{Steps to improve the fluency of read- ing in the classroom with the Software of Natural reader}

Motivation: in order that the students to read, students must be motivated. To achieve this, students should often be given the opportunity to listen to stories or passages that readers naturally read and students should also be required to read for others. Students should be given a number of reading materials from various genres of reading materials in class, this is very important to trigger their reading interest

Practice: Students should be given plenty of time to listen to the story being read and after students have listened to the story or passage that readers naturally read frequently, ask them to reread the story or part of the story they have heard. This is an excellent way to use a recording device and ask them to record themselves. Choir reading (all students in the class must read together) and pair reading (one student reads with another). This method is also very good to do regularly in class.
Modeling: Every day Natural Reader must set an example of how to read fluently properly and teachers should always motivate students to keep practicing to do the same. Students who continue to practice basic decoding skills may benefit from echo reading where Natural Reader reads short phrases of 3-5 words and students pronounce the same phrases. By adopting this method, Natural Reader will model and allow present readers to practice reading them all at the same time. This is a powerful way of learning to read to increase students' self-confidence. It is recommended that the position of Natural Reader can be replaced by a teacher on the condition that the teacher has perfect oral reading fluency

Help: Teachers are obliged to assist in improving self-correction skills by motivating students to listen to themselves read and monitor their reading. After students read the reading material that has been selected, the teacher must teach students to ask students themselves, it is very important for all teachers to show students how to use graphics, illustrations, to help students to know what they have read.

Directions for Administration (Christ et al., 2013)

1. Students and testers sit opposite each other. The examiner gives an unnumbered copy of the Curriculum-Based Measurement $(\mathrm{CBM})$ reading passage to the student. The examiner takes a copy of the numbered section, protecting it from the student's view.

2. Students were told by the examiner: "When I say the word 'start', you immediately read aloud at the top of this page. Pointing, the teacher says: "Read all the pages and try to read every word". When you read and come to a word that you do not understand, I will definitely tell it to you. Read it well. Any question?

3. When students say the first word. At that moment the examiner started his stopwatch. If within 3 seconds the student does not say the first word, the tester will say the word and start the stopwatch

4. When the text is read by the students, at that time the error is noted by the examiner by putting a slash (/) exactly on the word that was read incorrectly by the student. If students are confused and doubtful and do not immediately read for 3 seconds, then the word will be spoken by the examiner and at the same time, the examiner marks the word as an error.

5. The tester will say, "Done" in less than 1 minute. And at that time, the examiner put 
brackets (]) in place of the student's conclusion in the text

6. Preliminary Assessment: If the examiner assigns to grade a student for the first time, the examiner will administer a total of 3 passages of reading during the session using the above procedure, and the median score (middle score) will be taken as the best interpretation of fluency. student oral reading. Progress-Monitoring: If the examiner checks the student's fluency progress in oral reading (and has previously collected ORF data), and the examiner will give one reading passage only in the session.

The formula of the Fluency of Oral Reading adapted from Masters 2009

Formula of Fluency Rate if Student reads for 60 Seconds

$$
\mathrm{WCPM}=\mathrm{A}-\mathrm{B}
$$

WCPM $=$ Word Correct Per Minute (Fluency)

$A=$ Total Words Attempted in Story in 60

Seconds

$\mathrm{B}=$ Errors

Formula of Fluency Rate if Student has Completed Passage in Less than $60 \mathrm{Se}$ conds

$$
\mathrm{WCPM}=\frac{\mathrm{C}-\mathrm{D}}{\mathrm{E}} \times 60
$$

$\mathrm{WCPM}=$ Word correct Per Minute

(Fluency)

$\mathrm{C}=$ total words the students read

$\mathrm{D}=$ errors

$\mathrm{E}=$ total seconds

\section{Scoring}

The examiner first calculates fluency in reading the text to determine the total number of words that have been read, then the examiner will subtract the total number of words read incorrectly. This method is very helpful for the examiner in getting the reading probe: Errors in pronouncing will be counted as errors

Example

Text: The small /smol/ black cat ran to catch the mouse.

Student: "The small /smoul/black cat ran to catch the mouse."

\section{Errors also deal with the Substitutions}

Example

Text: After finishing football, he immediately takes a shower in the bathroom
Student: After finishing soccer, he immediately took a shower in the bathroom

\section{Errors also deal with the omission}

Example

Text: Rossy did not drive in the first round.

Student: " Rossy did not ------- in the first round.."

Word transpositions -pairs are calculated as 1 mistake.

Example

Text: Jane could not bring a such very heavy box

Student: " Jane could not bring a very such heavy box

Hesitations (waiting 3 seconds).

the examiner should read the words to the student after 3 seconds have gone by are calculated as errors. In this situation, the teacher provides the words and the student moves on reading the text

\section{Assessing Reading Speed With CBM: the Flu- ency of Oral Reading Passages \\ Description}

CBM-ORF can be used to measure a student's reading fluency by asking the student to read aloud for 1 minute from the prepared section. As long as the students are reading, the examiner must keep a record of each student's reading errors. Then the examiner must assess the section by counting the number of words that have been read correctly (Christ et al., 2013).

\section{Preparation}

The section that has been selected should not contain a lot of dialogue and this should avoid an excessive number of foreign words or phrases in other words all the words must be at the level of the student's ability. In addition, Dan only in the prose section should be used in the CBM assessment. Poetry and drama should be avoided because Poetry and drama tend to be very varied and cannot represent every type of text that students usually encounter. To make administration easier, instructors should always prepare copies of examiners and students from each section. Ideally, part of the reading should not contain illustrations which in turn can help students to interpret the contents of the text. The test copy should have the cumulative word total listed along the right margin of the section for ease of assessment (Christ et al., 2013).

Show Figure 1. To read the assessment probe. First, the rater must determine the number of words that must be read in 1 minute. See in Figure 2, for example, if there are brackets near the end of the reading indicating that the student 
Journal Of Development Research, 5 (2), November 2021, Pages 156-163

\begin{tabular}{|c|c|}
\hline Examiner copy & Student copy \\
\hline $\begin{array}{l}\text { The flood damaged crops in farmers' fields very badly } \\
\text { (9) }\end{array}$ & The flood damaged crops in farmers' fields very badly \\
\hline $\begin{array}{l}\text { the rainy season allows farmers to plant rice in the } \\
\text { fields }\end{array}$ & the rainy season allows farmers to plant rice in the fields \\
\hline $\begin{array}{c}\text { in winter season many animals are cold and trees are } \\
\text { frozen }\end{array}$ & in winter season many animals are cold and trees are frozen \\
\hline $\begin{array}{l}\text { traders find it difficult to sell their wares during pan- } \\
\text { demic }(41)\end{array}$ & traders find it difficult to sell their wares during pandemic \\
\hline $\begin{array}{l}\text { many people are starving due to crop failure in their } \\
\text { area }\end{array}$ & many people are starving due to crop failure in their area \\
\hline
\end{tabular}

Figure 1: Example of CBM the Fluency Probe of Oral Reading

\begin{tabular}{|lc|}
\hline The flood damaged crops in farmers' fields very badly & $(9)$ \\
\hline the rainy season allows farmers to plant rice in the fields & $(20)$ \\
\hline in the winter season many animals are cold and trees are frozen & $(31)$ \\
\hline traders find it difficult to sell their wares during pandemics & $(41)$ \\
\hline many people are starving due to crop failure in their area & $(52)$ \\
\hline Total read words & $(52)$ \\
\hline Error & $(4)$ \\
\hline Correctly read words & $(48)$ \\
\hline
\end{tabular}

Figure 2: Example of a scored reading probe

\begin{tabular}{|lc|}
\hline The flood-damaged crops in farmers' fields very badly & $(9)$ \\
\hline in winter season many animals are cold and trees are frozen & $(20)$ \\
\hline traders find it difficult to sell their wares during pandemics \\
\hline many people are starving due to crop failure in their area \\
\hline Total read words \\
\hline Error & $(41)$ \\
\hline Omission Error & $(11)$ \\
\hline Correctly read words & $(37)$ \\
\hline
\end{tabular}

Figure 3: A reading probe marked for words omitted

has tried 52 words before the allotted time runs out. Furthermore, the number of errors that have been made by the reader must be counted by the examiner. it is evident that a number of students have made 4 errors in this experiment. The examiner subtracts the number of word errors from the total number of words attempted, thus finding the number of words read correctly per minute. Estimation of reading fluency, combining the speed and accuracy of students in reading is largely de- termined by the words read correctly per minute. So the errors found from the total words tried, it can be found that students read 48 correct words in 1 minute (Christ et al., 2013).

When scoring omissions should be accommodated...

If some words or even all words are skipped by students during reading, then the omission will make a special dilemma in scoring. However, an omission is considered an 
Journal Of Development Research, 5 (2), November 2021, Pages 156-163

\begin{tabular}{|l|c|c|c|}
\hline \multicolumn{1}{|c|}{ Group } & Pretest- & Observation & Posttest \\
\hline Control-Group & $\mathrm{Y}_{1}$ & - & $\mathrm{Y}_{2}$ \\
\hline Experiment-Group & $\mathrm{Y}_{1}$ & $\mathrm{X}$ & $\mathrm{Y}_{2}$ \\
\hline
\end{tabular}

Figure 4: The Design Applied in This Recent Study

Table 1 : Between-Subjects Effects Test

\begin{tabular}{|l|r|r|r|r|r|}
\hline \multicolumn{7}{|c|}{ Between-Subjects Effects Test } \\
\hline Source & $\begin{array}{c}\text { Type III Sum } \\
\text { of Squares }\end{array}$ & \multicolumn{1}{c|}{ df } & Mean Square & \multicolumn{1}{c|}{ F } & \multicolumn{1}{c|}{ Sig. } \\
\hline Corrected Model & $244586.125^{\mathrm{a}}$ & 3 & 81528.708 & 35.425 & .000 \\
\hline Intercept & 213894.327 & 1 & 213894.327 & 92.939 & .000 \\
\hline MEDIA & 22482.255 & 1 & 22482.255 & 9.769 & .003 \\
\hline PRETEST & 284.886 & 1 & 284.886 & .124 & .726 \\
\hline $\begin{array}{l}\text { MEDIA * PRE- } \\
\text { TEST }\end{array}$ & $\mathbf{6 5 . 0 3 0}$ & $\mathbf{1}$ & $\mathbf{6 5 . 0 3 0}$ & $\mathbf{. 0 2 8}$ & $\mathbf{. 8 6 7}$ \\
\hline Error & 144991.069 & 63 & 2301.446 & & \\
\hline Total & 2629316.000 & 67 & & & \\
\hline Corrected Total & 389577.194 & 66 & & & \\
\hline
\end{tabular}

error, and no matter how many words are skipped. The student error rate is greatly increased when all the words omitted in a line are counted as an error.

Figure 3 illustrates the existence of a complete examination. The student does not fill in the text of the entire line when he reads aloud. The examiner draws a line through all the connected words that are not filled in by the student in the omitted line of text. Since a overall of 11 words are skipped, the examiner drops those 10 words before counting the total words tried.

When students read the text, at that time the number of words was counted and the examiner noted that a number of 48 words had been achieved by the students. there are 11 words that are skipped by students and this number is used to reduce the number of 48 words that are read so that they become 39 words. And the number of 39 words was reduced by 4 words that were misread by students so that the total number of correct words read by students was 37 words.

\section{Method}

A quantitative approach was applied in this study because the data taken from the respondents were interval data, namely the value of oral reading fluency. While the method used was quasiexperimental, and nonrandomized pretest-posttest control group design was the right research design to be used (Ary, Donald, LUCY CHESER JACOBS, 2010)

The English department students of UNIPA Blitar, Indonesia were the subjects of the recent study. Group (1) has 32 students, the teacher taught them using Natural Reader software, and this group was called the experimental group. Group (2) as the control group.had 35 students, the teacher taught them by using conventional teaching media. The control group is taught in the regular class, while the experimental group is taught in the language laboratory

Y1: Pre-test Observation

Y2: Observation in Posttest

$\mathrm{X}$ : Observation of Natural Reader Software

The formula used to prove the hypothesis was ANCOVA, and to get fast and accurate calculation results, the researcher used SPSS software.

\section{Result And Discussion}

Testing the homogeneity of regression slopes Based on the data in the Table 1 , it is clear that the value of .867 is greater than .05 . This means that the assumption of homogeneity of the regression slope is not problematic, therefore, ANCOVA analysis can be applied.

\section{Test of Equality}

Based on the table 2 Sig value of .2503 and this value greater than .05 , it can be concluded that the variance is homogeneous, in other words the assumption of the variance equation is not problematic. 
Table 2 : Test of Equality

\begin{tabular}{|c|c|c|c|}
\hline $\mathrm{F}$ & $\mathrm{df1}$ & $\mathrm{df2}$ & Sig. \\
\hline 1.3457 & 1 & 65 & .2503 \\
\hline
\end{tabular}

Table 3 : The Covariance -One-way Analysis

\begin{tabular}{|c|c|c|c|c|c|}
\hline \multicolumn{7}{|c|}{ Between-Subjects Effects Test } \\
\hline Source & $\begin{array}{c}\text { Type III Sum } \\
\text { of Squares }\end{array}$ & df & Mean Square & F & Sig. \\
\hline $\begin{array}{c}\text { Corrected } \\
\text { Model }\end{array}$ & $244521.096^{\mathrm{a}}$ & 2 & 122260.548 & 53.942 & .000 \\
\hline Intercept & 995073.718 & 1 & 995073.718 & 439.035 & .000 \\
\hline PRETEST & 847.592 & 1 & 847.592 & .374 & .543 \\
\hline MEDIA & $\mathbf{2 4 2 0 3 0 . 5 9 1}$ & $\mathbf{1}$ & $\mathbf{2 4 2 0 3 0 . 5 9 1}$ & $\mathbf{1 0 6 . 7 8 7}$ & $\mathbf{. 0 0 1}$ \\
\hline Error & 145056.099 & 64 & 2266.502 & & \\
\hline Total & 2629316.000 & 67 & & & \\
\hline Corrected Total & 389577.194 & 66 & & & \\
\hline
\end{tabular}

Table 4 : Calculation of Average Marginal Estimate

\begin{tabular}{|c|c|c|c|c|}
\hline \multicolumn{5}{|c|}{ MEDIA } \\
\hline MEDIA & Mean & Std. Error & \multicolumn{2}{|c|}{$95 \%$ Confidence Interval } \\
\cline { 4 - 5 } & & Lower Bound & Upper Bound \\
\hline $\begin{array}{c}\text { Software of Natural } \\
\text { Reader }\end{array}$ & $247.507^{\mathrm{a}}$ & 8.474 & 229.581 & 263.434 \\
\hline $\begin{array}{c}\text { Conventional Media } \\
\text { Conny }\end{array}$ & $125.623^{\mathrm{a}}$ & 8.098 & 108.448 & 140.799 \\
\hline
\end{tabular}

\section{The Covariance -One-way Analysis}

Based on the calculation results shown in the Table 3, namely: $\mathrm{F}(1,64)=\mathrm{F} 106,787, \mathrm{P}=0.001$ $<.05$. It is accepted that the null hypothesis is rejected. In other words, there is a difference in the average value of the two groups.

\section{Calculation of Average Marginal Estimate}

Based on the table 4, students who were taught using Natural Reader software had an average value of greater than that of students who were taught using conventional media, which is 247,507 $>125,623$.

\section{Conclusion}

It was proven that students who were taught using Natural Reader software had more accurate reading skills and also had more precise speed. It was proven that the use of Natural Reader Software could stimulate students to listen to native speakers through the software. The results of this study also had similarities with previous research conducted by (Demars \& Erwin, 2005). They has declared that oral reading fluency could develop reading skills.

\section{References}

Analyzing Grammar - Google Books. (n.d.). Retrieved October 29, 2021, from https:// www.google.co.id/books/edition/ Analyzing_Grammar/rSglHbBaNyAC? $\mathrm{hl}=\mathrm{en} \& \mathrm{gbpv}=1 \& \mathrm{dq}=$ Kroeger. + (2005).+Analyzing+Grammar.+Cambridg $\mathrm{e}+$ University + Press\&printsec $=$ frontcover

Ary, D., Jacobs, L. C., Sorensen, C. K., \& Walker, D. A. (n.d.). Introduction to research in education.

Introduction to Integrated Education - Google Books. (n.d.). Retrieved October 29, 2021, from https://www.google.co.id/ books/edition/

Introduction_to_Integrated_Education/ $\mathrm{z} 4 \mathrm{~s} 0 \mathrm{EAAAQB} \overline{\mathrm{J}}$ ?

$\mathrm{hl}=\mathrm{en} \& \mathrm{gbpv}=1 \& \mathrm{dq}=$ sorogan + method $\& \mathrm{p}$ $\mathrm{g}=$ PA114\&printsec $=$ frontcover

Islam, the State and population. (2005). 286.

Islamic Education and Indoctrination - Google Books. (n.d.). Retrieved October 29, 
2021, from https://www.google.co.id/books/ edition/

Islamic_Education_and_Indoctrination/

$\mathrm{NuWrAgAAQBAJ}$ ?

$\mathrm{hl}=$ en $\& \mathrm{gbpv}=1 \& \mathrm{dq}=$ what + is + sorogan + metho $\mathrm{d} \&$ pg $=$ PA1 19\&printsec $=$ frontcover

Kroeger, P. R. (2005). Analyzing Grammar. Cambridge University Press.

Mikulecky S., B., \& Jeffries, L. (2007). Advanced Reading Power. Pearson Education.

Nizar, S. (2013). Sejarah sosial \&amp; dinamika intelektual pendidikan Islam di Nusantara. 371.

Pendidikan Karakter Berbasis Budaya Pesantren Google Books. (n.d.). Retrieved October 29, 2021, from https://www.google.co.id/books/ edition/

Pendidi-

kan_Karakter_Berbasis_Budaya_Pesa/

X27IDwAAQBAJ?

$\mathrm{hl}=\mathrm{en} \& \mathrm{gbpv}=1 \& \mathrm{dq}=$ Pola ++ Pembelajaran $+\mathrm{di}$

$+\mathrm{Pe}-$

santren.+Jakarta:+Dirjen+Kelembagaan+Aga ma+RI\&pg=PA58\&printsec $=$ frontcover

Practice and Progress - Google Books. (n.d.). Retrieved October 31, 2021, from https:// www.google.co.id/books/edition/

Practice_and Progress/383TAQAACAAJ?

$\mathrm{hl}=\mathrm{en} \& \overline{\mathrm{sa}}=\mathrm{X} \dot{\mathrm{E}} \mathrm{ved}=2 \mathrm{ahUKEwjLyeXjyvTzAh}$ Wi7XMBHXLkBPwQiKUDegQIChAH

Pulungan, J. S. (n.d.). Sejarah pendidikan Islam. 452.

Schmidt, N. A., \& Brown, J. M. (Janet M. (2012). Evidence-based practice for nurses : appraisal and application of research. 522 .

Tohir, K., \& Lubis, M. S. A. (2020). MODEL PENDIDIKAN PESANTREN SALAFI. https:// books.google.co.id/books?

$\mathrm{id}=\mathrm{c} 2 \mathrm{ABEAAAQBAJ}$

Turmudi, E. (2006). Struggling for the Umma: changing leadership roles of kiai in Jombang, East Java. 214.

Ummah Karimah. (2018). ETHNIC DIVERSITY IN TEACHING SOROGAN OF PESANTREN. JOMSIGN: Journal of Multicultural Studies in Guidance and Counseling, 2 (2), 92-103. 